\title{
O conto "Adão e Eva": a criação do mundo é obra do Diabo
}

Resumo: Este trabalho tem como intuito apresentar uma das figuras mais importantes do imaginário Ocidental, o Diabo, tal como este se apresenta pelas tintas do escritor, Joaquim Maria Machado de Assis. Para tanto, nos propomos realizar a leitura do conto "Adão e Eva", no qual o Diabo comparece explícito, como personagem, demonstrando de que forma ele foi apropriado pela literatura machadiana. E ainda procuraremos mostrar de que modo Machado de Assis reinterpreta o papel do Diabo na criação da humanidade.

Palavras-chaves: Machado de Assis - Bíblia - Diabo.

Abstract: This work intends to present one of the most important figures of the Western imaginary, the Devil, as presented by the painter 's paintings, Joaquim Maria Machado de Assis. To do so, we propose to read the tale "Adão e EVA", in which the devil appears explicit, as a character, demonstrating how it was appropriated by Machado literature. And we will also try to show how Machado de Assis reinterprets the role of the Devil in the creation of humanity.

Keywords: Machado de Assis - Bible - Devil.

\section{Introdução}

O diabo é possivelmente imortal, mas certamente surgiu em dado momento. Ele nada na correnteza do tempo, quiçá a dirige, ele é histórico no sentido estrito do termo. É possível a afirmativa de que o tempo começou com o diabo, que o seu surgir ou a sua queda representam o início do drama do tempo, e que "diabo" e "história" são dois aspectos do mesmo processo. Assim poderíamos afirmar que a nossa tentativa de fugir do diabo é um outro aspecto da nossa tentativa de emergir da temporalidade e ingressar no reino das Mães imutáveis (FLUSSER, 2006, p. 21).

O conto "Adão e Eva" foi publicado no livro Várias Histórias, em 1896. Machado de Assis reinterpretou a história da criação, contida no livro do Gênesis, recriando-a de modo diferente se comparada com o texto original. De fato, essa nova roupagem atribuída à história da criação pelo autor põe em evidência uma figura tão importante para o imaginário Ocidental quanto Deus: o Diabo, nos levando a repensar o papel do Diabo, que foi igualmente decisivo na história da humanidade. Assim, Machado se apropriou do texto bíblico, modificando-o: introduziu a figura do Diabo que não aparece no terceiro capítulo do livro do Gênesis. A narrativa do conto tem início na casa de D. Leonor, senhora de engenho, que promovia uma reunião íntima entre os amigos. Ao anunciar aos seus convivas, que iria

\footnotetext{
${ }^{1}$ Mestra e doutoranda da Universidade Federal de Juiz de Fora, professora substituta onde cursa o doutorado. E-mail: izabellaletras@gmail.com
} 
oferecer "certo doce particular" (ASSIS, 1997, p. 525), ela deixou um convidado tentado a saber que doce era. Observemos que é por meio deste acontecimento, que a conversa sobre Adão e Eva se desenvolverá. Então, o Sr. Veloso, convidado presente, e "insigne em teologia" (ASSIS, 1997, p. 525), afirmou que a história descrita na Bíblia não era a verdadeira, e que conhecia a original. Desse modo, apresentou a sua versão para todos. Ora, a partir da narração desse personagem, o escritor revisita à tradição, a fim de questioná-la. No conto, a história bíblica é narrada às avessas. Segundo o relato machadiano, a criação do mundo aconteceu da seguinte forma:

Foi o Tinhoso que criou o mundo; mas Deus, que lhe leu no pensamento, deixou-lhe as mãos livres, cuidando somente de corrigir ou atenuar a obra (...) tendo o Tinhoso criado as trevas, Deus criou a luz, e assim se fez o primeiro dia. No segundo dia, em que foram criadas as águas, nasceram as tempestades e os furacões; mas as brisas da tarde baixaram do pensamento divino. No terceiro dia foi feita a terra, e brotaram dela os vegetais, mas só os vegetais que matam como a cicuta; Deus, porém, criou as árvores frutíferas e os vegetais que nutrem e encantam. E tendo o Tinhoso cavado abismos e cavernas na terra, Deus fez o sol, a lua e as estrelas; tal foi a obra do quarto dia. No quinto dia foram criados os animais da terra, da água e do ar (ASSIS, 1997, p. 525-526).

Como podemos notar, nesta nova versão, o mundo não foi criado por Deus, mas sim pelo Diabo. E ao Senhor coube o papel de coadjuvante desta obra, pois a ele só sobrou a tarefa de corrigir a criação do mal, através do bem. Como sabemos, no texto bíblico, a capacidade de criar, é atribuída exclusivamente a Deus, que detém todo o poder. De fato, ao modificar o sujeito do processo criador, Machado põe em dúvida o poder de Deus.

Vale pontuar as considerações do pesquisador Fernando Machado Brum, em Literatura e Religião: Estudo das referências religiosas na obra de Machado de Assis, a respeito desse conto. De acordo com ele, as etapas da criação são feitas em total desarmonia com o texto bíblico, mas ao mesmo tempo, essas etapas, em uma determinada ocasião, terminam se harmonizando com a narrativa bíblica. Brum diz que:

\begin{abstract}
Não menos importante são as etapas da criação, todas feitas em interessante desarmonia conciliatória com o texto bíblico. Desarmonia, porque tira de Deus a função criativa que lhe é historicamente colocada, dentro da tradição monoteísta, de ser o único criador que tudo faz através de sua Palavra (que para a tradição cristã é o próprio Cristo); conciliatória, porque, apesar de Deus conceder ao Diabo a possibilidade criativa - diga-se de passagem, ideia muito pouco comum nas tradições politeístas e dualistas - vai pouco a pouco consertando a obra diabólica e, desta forma, criando o que tem de melhor na terra (BRUM, 2009, p. 139).
\end{abstract}

Em partes, coadunamos com esse argumento, posto que Machado desconstrói o texto bíblico ao atribuir ao Diabo à competência de criar o mundo. Contudo, quando o autor concede a Deus a capacidade de consertar aquilo que o Diabo fez, através do bem, conciliase com a ideia da Bíblia de que Deus realizou tudo o que é bom. No entanto, defendemos que o autor machadiano, ao modificar os sujeitos do processo da criação, está dialogando com a narrativa bíblica com o intuito de criticar o poder atribuído lá, a Deus.

Principiemos por observar como o relato bíblico se inicia, primando em trazer explicações de como a terra surgiu: "No princípio, criou Deus os céus e a terra. E a terra era sem forma e vazia; e havia trevas sobre a face do abismo" $(G n, 1,1)$. No conto, tal informação não é dita, tendendo o texto a ser bem direto e objetivo.

Em "Adão e Eva", vemos que o narrador não esclarece a respeito da origem dos

https://periodicos.unifap.br/index.php/letras

Macapá, v. 8, n. 3, $2^{\circ}$ sem., 2018 
personagens: Diabo e Deus. Não sabemos quem são? De onde eles vieram? O que motivou o Diabo a criar o mundo? E de onde provinha o Diabo quando criou as suas obras, e Deus onde estava quando corrigia a criação do Diabo? Logo, ao consultarmos as Escrituras, percebemos que Machado adotou o mesmo princípio utilizado na Bíblia, visto que, no texto bíblico, não nos é apresentado nada sobre a vida de Deus, não conhecemos a sua procedência, nem ao menos sabemos, realmente, o que o motivou a criar o mundo. $\mathrm{Na}$ verdade, a figura de Deus surge enigmaticamente e "entramos em cena com a obra em andamento" (MILES, 2009, p. 39).

Ressalta-se que essa característica é bem peculiar da narrativa bíblica, já que só são explorados os acontecimentos que interessam para o desenrolar da ação, o resto fica obscuro, sem explicação, cabendo ao leitor interpretar os espaços lacunares. Nesse sentido, o crítico Erich Auerbach em seu livro, Mimesis, nos esclarece sobre o estilo bíblico:

(...) só é acabado aquilo que nas manifestações interessa à meta da ação; o resto fica na escuridão. Os pontos culminantes e decisivos para a ação são os únicos a serem salientados; o que há entre eles permanece inconsistente; tempo e espaço são indefinidos e precisam de interpretação; os pensamentos e os sentimentos permanecem inexpressos: só são sugeridos pelo silêncio e por discursos fragmentários. O todo, dirigido com máxima e ininterrupta tensão para um destino e, por isso mesmo, muito mais unitário, permanece enigmático e carregado de segundos planos (AUERBACH, 2007, p. 9).

Em Machado, no primeiro dia, o Diabo criou as trevas, e Deus aperfeiçoou a criação, fazendo a luz. Todavia, vemos que, na Bíblia, o primeiro dia é assim descrito: "E disse Deus: Haja luz. E houve luz. E viu Deus que era boa a luz; e fez Deus separação entre a luz e as trevas" (Gn 1, 3-4). Desse modo, como podemos observar o autor, mudou o protagonista da criação, porém preservou o dia e a ordem, em que a luz foi criada. De acordo com as Escrituras, as trevas já existiam, antes da formação da terra, entretanto, no conto, ela foi criada, no primeiro dia, pelo Diabo.

É importante notar que o texto bíblico narra este episódio com mais riquezas de detalhes. Nele, temos a explicação de como a terra foi originada: Deus, a partir de sua palavra, dá a ordem, em discurso direto, e a criação começa a existir, logo todo poder e autoridade provém, exclusivamente, Dele. E ainda, privilegia-se a descrição da ação de Deus de "ver" que a obra criada era boa, assim temos a revelação da aprovação divina e a qualidade da criação enfatizadas. No conto, entretanto, o autor não explicita de que forma o Diabo fez o mundo, e nem destaca a qualidade da obra do Diabo e de Deus.

Outra minúcia do relato bíblico refere-se à fórmula: "E assim foi” $(G n 1,11)$, aparecendo sempre depois das coisas serem concebidas, significando a confirmação da ordem de Deus, pois tal como ele disse aconteceu. No entanto, quando lemos o temos machadiano não encontramos essa justificativa, visando comprovar que as obras do Diabo e de Deus foram realizadas, de acordo com o desejo deles. Vale lembrar que a narrativa bíblica ainda tem um caráter diferente do conto, possuindo a pretensão de que a realidade narrada constitua-se como verdadeira. Neste contexto, o narrador bíblico pretende tornar o texto o mais convincente possível, buscando que esse se revele como uma verdade absoluta, objetivo que autor machadiano parece não perseguir.

No terceiro dia, no conto machadiano, verificamos que o Diabo fez a terra, as ervas e os vegetais, todavia é evidente, que com o detalhe de imperfeição: os vegetais foram concebidos sem fruto e flor e as ervas deveriam matar, mas Deus aprimorou a criação, através das árvores frutíferas e ervas verdes. Em Gênesis, Deus criou a terra, o mar, as ervas e as 
árvores, assim lemos na Bíblia: "E disse Deus: Ajuntem-se as águas debaixo dos céus num lugar; e apareça a porção seca. (...) E chamou Deus à porção seca Terra; e ao ajuntamento das águas Mares. (...) E disse Deus: Produza a terra erva verde, erva que dê semente, árvore que dê fruto segundo a sua espécie” (Gn 1, 9-11).

Neste sentido, quando comparamos os textos, reparamos que Machado preserva quase todos os elementos que foram feitos pelo Deus da Bíblia, porém não menciona a existência da criação do mar. Além disso, o relato bíblico sugere a diversidade de espécies, a partir da fala de Deus, que ordenou a todas as coisas criadas a produção de frutos, conforme a sua espécie. De fato, Machado não conferiu ao seu Diabo tal capacidade.

Diante disso, é notável que o texto machadiano nos oferece uma descrição mais geral do que a do original, não primando em aprofundar nos detalhes, e muito menos em trazer explicações. Fica evidente também, que o escritor machadiano não enfoca as falas dos personagens, em questão, do Diabo e de Deus, apenas relata o resultado de suas ações, tal recurso confere à narração um caráter mais estático, entretanto, no texto bíblico, a narração é mais dinâmica, à medida que a fala de Deus é destacada.

No quarto dia, o Diabo do conto fez surgir os abismos e cavernas, e Deus corrigiu essas obras, através do sol, da lua e das estrelas. Em Gênesis, nesse dia, de modo semelhante, os elementos o sol, a lua e as estrelas foram feitos por Deus. Logo, Machado modifica este trecho bíblico, no entanto busca preservar a ordem, no qual as coisas foram concebidas:

E disse Deus: Haja luminares na expansão dos céus, para haver separação entre o dia e a noite [...] E fez Deus os dois grandes luminares: o luminar maior para governar o dia e o luminar menor para governar a noite; e fez as estrelas. E Deus os pôs na expansão dos céus para alumiar a terra, e para governar o dia e a noite, e para fazer separação entre a luz e as trevas $(G n 1,14$; 16-18).

Comparemos que no texto original bíblico, Deus não apenas realizou o ato da criação, mas explicou o motivo de tais coisas serem criadas, explicitando a necessidade do surgimento de tais elementos, já que deveriam governar o dia e a noite, fazer a separação entre a luz e as trevas, além de especificar o lugar direcionado para onde eles deveriam permanecer, no céu. $\mathrm{Na}$ verdade, Machado suprimiu estas informações, contudo nota-se que, no conto, não é essencial separar a luz e as trevas, pois a dinâmica dessa separação já foi bem estabelecida: desde o princípio o mal está dissociado do bem.

Em “Adão e Eva”, recordemos que, no quinto dia, foram originados os animais, bem como acontece na história bíblica: "E Deus criou as grandes baleias, e todo réptil de alma vivente que as águas abundantemente produziram conforme as suas espécies, e toda ave de asas conforme a sua espécie" $(G n, 1,21)$. Contudo, uma observação atenciosa evidencia que o texto machadiano, somente apontou que tal obra foi realizada, e não vemos a ação do Diabo e nem de Deus, uma vez que não é verdade que o Diabo cria e Deus conserta? Aqui, esta informação não aparece, ora o autor apropriou-se desta parte bíblica sem modificá-la.

Sublinhemos que no relato bíblico, depois de formados os animais, Deus manifestou a benção sobre as suas criaturas, e a ordem de que elas poderiam se multiplicar: "E Deus os abençoou, dizendo: Frutificai, e multiplicai-vos, e enchei as águas nos mares; e as aves se multipliquem na terra" ( $G n$ 1, 22). Entretanto, podemos observar que Machado, em nenhum momento, trata sobre esta questão, o Diabo e Deus só desempenham a função de criarem, a eles não é dado o poder de amaldiçoarem ou abençoarem as suas próprias criações. Vale comentar que nesta primeira parte, o texto bíblico preocupou-se, em enfatizar, 
de forma bem detalhada todo o processo da criação, evidenciando o quão grandioso e poderoso, é o personagem Deus.

Em contrapartida, Machado nos apresenta a origem da terra, segundo a ordem primeira do Diabo, de forma bem sucinta, privilegiando só o resultado do processo criativo tanto do maligno quanto de Deus. Neste contexto, o escritor parece destacar a figura do Diabo, que, no conto, é o protagonista da ação, como detentor da capacidade criativa e de um grande poder para modificar a realidade.

Vale destacar que a pesquisadora Andreia Amaral em seu artigo, Travessias nos jardins das delícias: Machado e Eça, comenta que: "Machado de Assis transforma a criação numa obra 'a quatro mãos', entre Deus e o Diabo" (AMARAL, 2004, p. 340). Desse modo, tal assertiva corrobora por enfatizar que no conto machadiano, a formação da terra não é um ato exclusivo de um único ser, como descrito na Bíblia, mas que é compartilhado por duas forças antagônicas que se atraem e completam a criação.

\subsection{O Diabo e suas criaturas: Adão e Eva}

Definiremos portanto a Terra como o propósito de máquina celeste. O diabo criou os céus, para criar a Terra. E criou a Terra, para criar a vida. E criou a vida, para criar a humanidade. E criou a humanidade, para criar o espírito humano, esse espírito que conhece o Bem e o Mal, portanto o campo do pecado. Em outras palavras: a Terra é o palco do pecado. É ela a oficina na qual o diabo forja a sua arma para a conquista da realidade: o espírito humano. Essa obra forjada continua progredindo, e a arma ainda está longe de ser perfeita (FLUSSER, 2006, p. 45).

No conto de Machado de Assis, vemos que, no sexto dia, o Diabo foi o responsável por criar os homens, com o detalhe da beleza, da ausência de alma e da maldade: "(...) no sexto dia foi criado o homem e logo depois a mulher; ambos belos, mas sem alma, que o Tinhoso não podia dar, e só com ruins instintos" (ASSIS, 1997, p. 526). Na história original, no sexto dia, Deus também fez a espécie humana: "Façamos o homem à nossa imagem, conforme a nossa semelhança" (Gn 1, 26). (Grifo nosso)

É interessante sublinhar aqui a obscuridade do relato bíblico, pois parece que Deus não estava só quando criou o homem. Ora, quem estava com ele neste momento? Era o Diabo? Isto o texto sagrado não informa. Contudo, Machado atribui exclusivamente a autoria dessa obra ao Diabo não deixando nenhuma dúvida, quanto ao processo criativo. É possível observar ainda que no conto, o autor descreve-nos que primeiro o homem foi criado, depois a mulher. Até aqui nenhuma novidade, mas, no texto original, encontramos o esclarecimento de que a mulher foi concebida, a partir das costelas do homem (Gn 2, 21-22).

Como vimos, no relato bíblico, Deus criou o homem a sua imagem e semelhança. No conto, Machado conservou a ideia do texto original, porém fazendo uma pequena modificação: o Diabo fez os homens "sem alma" (ASSIS, 1997, p. 526) e com "ruins instintos" (ASSIS, 1997, p. 526), entretanto, eles não eram horríveis, como seria presumível, mas sim "belos" (ASSIS, 1997, p. 526). De fato, tal interpretação contraria à tradição cristã, que sempre associou a falta de alma e os instintos ruins ao feio ou grotesco.

Em "Adão e Eva", Deus reparou a obra do Diabo, infundindo nos homens alma e bons sentimentos, através de um sopro, então lemos: "Deus infundiu-lhe almas com um sopro, e com outro os sentimentos nobres, puros e grandes" (ASSIS, 1997, p. 526). Na narrativa bíblica, ocorre um pouco diferente, Deus formou o homem, por meio do pó da terra, e soprou-lhe o fôlego da vida: "E formou o Senhor Deus o homem do pó da terra e 
soprou em seus narizes o fôlego da vida" (Gn 2, 7). Como vemos, o escritor brasileiro modifica o texto original.

Notemos que em ambos os textos, o "sopro" simboliza a relação de Deus com os seres humanos. Dessa maneira, observamos, nas Escrituras, logo depois de gerado o homem, Deus realizou uma série de ações: abençoou a sua criação, ordenou ao homem que se multiplicasse, e ainda o fez participar do processo de seu ato criador, na medida em que pediu a Adão, para que nomeasse todos os animais da terra. Já, no conto, lemos que Machado vai construindo a sua estória sem enfatizar tais minúcias. Cabe ainda comentar que o escritor não registrou nenhuma ação no sétimo dia bíblico, conforme as Escrituras, foi, nesse dia, que o Senhor descansou $(G n 2,2)$.

\subsection{Os filhos do Diabo e o paraíso}

Segundo a Bíblia, Deus fez um jardim destinado aos homens ( Gn 2, 8). No conto, se o Diabo é responsável por conceber a Terra, Deus criou o paraíso: "Deus (...) fez brotar um jardim de delícias, e para ali os conduziu, investindo-os na posse de tudo" (ASSIS, 1997, p.526). Entretanto, ao confrontarmos os dois textos, sublinhamos algumas diferenças, vejamos: em "Adão e Eva", o narrador nos demonstra a reação do casal, quando Deus os conduziu ao jardim: caíram "aos pés do Senhor" com "lágrimas de gratidão" (ASSIS, 1997, p. 526).

Ao consultarmos o texto original, não encontramos nenhuma descrição a respeito da reação dos homens, quando chegaram também ao local, feito pelo Senhor. De fato, diante do "magnífico" presente de Deus aos homens, o paraíso, Machado incluiu a gratidão de Adão e Eva, assim, vemos que ao longo do texto machadiano, os pensamentos e os sentimentos dos seus personagens são bem expressos, nada fica oculto. Cabe pontuar que o relato bíblico especifica ainda, aonde esse jardim estava localizado, descrevendo-nos como um lugar real: "E plantou o Senhor Deus um jardim no Éden, da banda do oriente" (Gn 2, 8). Todavia, no conto, o autor machadiano apenas denominou o jardim de "delícias", idealizando-o como um lugar de prazeres.

De acordo com as Escrituras, Deus quis pôr as árvores frutíferas no paraíso, de modo que os homens pudessem se alimentar, e também a árvore da ciência do bem e do mal. No entanto, os proibiu de comer do fruto dessa árvore, porque, acaso comessem, morreriam: "E ordenou o Senhor Deus ao homem, dizendo: De toda árvore do jardim comerás livremente, mas da árvore da Ciência do bem e do mal, dela não comerás; porque no dia em que delas comeres, certamente morrerás" (Gn 2, 16-17).

Da mesma forma que, no conto, pois Deus permitiu ao casal comer dos frutos de todas as árvores, contudo os proibiu de provarem do fruto da árvore da vida, assim lemos: "Vivereis aqui, disse-lhe o Senhor, e comereis de todos os frutos, menos o desta árvore, que é a da ciência do Bem e do Mal" (ASSIS, 1997, p. 526). Neste sentido, notemos que no texto original, Deus esclareceu a razão de proibir os homens de comerem daquela árvore, em Machado, isso não acontece, Deus somente realiza a proibição. Cabe ainda destacar que quando nos detemos no texto bíblico, vemos que ele se apresenta um tanto complexo e obscuro, dado que não encontramos nele o esclarecimento do que levou Deus a criar a árvore da ciência. Ou, por que Deus resolveu colocar essa árvore em um lugar de destaque, no centro do jardim? E ainda, ao analisarmos a proibição de Deus, notamos que os homens não a compreendiam totalmente, uma vez que se eles só experenciavam o bem, como poderiam conhecer o que era o mal e a morte? Dessa maneira, no conto, fica evidente que os 
homens se comportaram com submissão, no momento que escutaram a ordem de Deus: "Adão e Eva ouviram submissos" (ASSIS, 1997, p. 526). De fato, o escritor ressalta-nos a posição de subordinação deles, diante de Deus. Já no texto bíblico, nada disso é manifestado, lá não sabemos qual foi à atitude do casal. A única informação concreta, que temos são as palavras do Senhor, logo os gestos e as expressões dos personagens não são exteriorizados, permanecendo como um enigma. Também em "Adão e Eva", observamos a caracterização da forma como o casal vivia no paraíso: "embebiam-se da contemplação" e "dormiam como dous anjos" (ASSIS, 1997, p. 526). Tal explicação não está presente, no original. Ora, como já apontado, o texto bíblico mostra-se de maneira lacunosa e inacabada, enquanto que Machado evidencia, no seu conto, as partes reticentes da narrativa das Escrituras.

\subsection{O Diabo e a serpente}

(...) se o homem deve dominar a terra (...) por que não lhe é permitido o conhecimento do bem e do mal? Não é oferecida ao homem nenhuma razão para que obedeça, a não ser uma que não faz nenhum sentido (MILES, 2009, p. 43).

No conto, no momento em que o Diabo tomou conhecimento do que Deus tinha feito com sua obra, ficou muito irritado, no entanto, não podendo entrar no paraíso, inesperadamente, encontrou a serpente, e dirigiu-se a ela, chamando-a de "serpe", "fel rasteiro", "peçonha das peçonhas" (ASSIS, 1997, p. 526), e lhe prometeu "ser a embaixatriz" (ASSIS, 1997, p. 526) de seu reino, caso cumprisse às suas ordens. De fato, sublinhamos que Machado explicita a figura do Diabo, mas quando consultamos a tradição cristã, percebemos que o maligno é identificado à figura da serpente. No Gênesis, ele comparece implicitamente, pois em nenhum momento, é feita menção ao nome dele, bem como comentou o exegeta Stefano Virgulin em Introdução à Bíblia:

Sabemos pela revelação posterior que esta serpente indica o diabo (...) que por inveja introduziu a morte no mundo (Sab 2,24) e ao qual Jesus chamou de bomicida desde o princípio (Jo 8,44), enquanto que o Apocalipse $(12,9)$ identifica-a de forma mais completa: o grande dragão, a serpente antiga que se chama Diabo e Satanás (VIRGULIN, 1975, p. 179).

Convém pontuar que para a tradição judaica, a serpente não representa um mal em si, constituindo-se mais como um personagem literário, tal como esclareceu Virgulin:

A serpente que aparece de sopetão como tentadora é pelo autor sagrado ligada à criação dos animais de 2,19: ela é uma das feras do campo que deviam fazer companhia ao homem e que dele haviam recebido o nome. Dessas feras é a mais astuta: a ideia geralmente difundida da astúcia da serpente provém de sua maneira de se deslocar, tortuosa e insinuante. Uma serpente que fala não é algo natural, e subentende-se que essa serpente é portadora dum demônio, segundo uma ideia também bastante espalhada no Antigo Oriente. Mas parece que o autor sagrado evita de propósito apresentar um ser superior como pertencente a um outro mundo, e insiste no seu caráter de animal criado por Deus, para evitar que os primeiros destinatários da narração fossem tentados a ver um ser divino, um outro deus em competição com Javé (VIRGULIN,1975, p. 179).

Contudo, como foi assinalado, na tradição cristã, a serpente foi relida como a imagem do mal, simbolizada pelo Diabo. Cumpre esclarecer que o escritor, parece seguir esta última interpretação. Na verdade, o Diabo machadiano conferiu à serpente a fala. E, logo, ela 
aceitou a proposta do maligno de tentar o casal, que vivia no paraíso. Observamos que em Gênesis, tais acontecimentos se dão de forma adversa: no original, o animal é descrito como o mais astuto de todos os bichos (Gn 3, 1). Neste sentido, o que motivou Deus ter concedido, especificamente, a um animal tal característica? Como sabemos esta explicação não nos é revelada. Ou ainda, de que forma a serpente adquiriu o dom da fala? Foi Deus que a criou assim ou o isso foi obra do Diabo?

Também isto não é mencionado no texto sagrado. Em "Adão e Eva”, o Diabo, conhecendo a proibição de Deus, ensinou como a serpente teria que proceder: o animal deveria oferecer o fruto da árvore da vida para um dos dois, através da sedução de comer a "fruta mais gostosa do mundo" e de "conhecer o próprio segredo da vida" (ASSIS, 1997, p. 527). Logo ela, decididamente, resolveu tentar Eva: "Vou; mas não falarei a Adão, falarei a Eva" (ASSIS, 1997, p. 527). Do mesmo modo que acontece na narração bíblica: a serpente tentou Eva, e não Adão, conforme comparece no conto:

(...) o Tinhoso (...)ouvindo um rumor no chão entre as folhas secas, olhou e viu que era a serpente. Chamou-a alvoraçado: Vem cá, (...) queres tu ser a embaixatriz de teu pai (...) A serpente fez com a cauda um gesto vago, que parecia afirmativo; mas o Tinhoso deu-lhe a fala (...) Foi, penetrou no paraíso, rastejou até a árvore do Bem e do Mal, enroscou-se e esperou. Eva apareceu daí a pouco (ASSIS, 1997, p. 526-527).

Assinalamos ainda que o autor, ao introduzir a personagem serpente, pela primeira vez, descreveu pormenorizadamente, de que forma ela apareceu na história, como adquiriu a possibilidade de falar, qual a circunstância que a fez entrar no paraíso e o local onde o animal estava, quando encontrou Eva. Na verdade, vemos, no texto machadiano, a necessidade de exteriorização dos fenômenos, esses são representados de forma acabada, e visíveis em todas as suas partes.

\subsection{A serpente e o casal}

A serpente, no conto machadiano, seguindo as recomendações do Diabo, enroscou-se na árvore da ciência à espera de Eva, no momento que a avistou ficou, "mordida de inveja, ia chamar a peçonha à língua" (ASSIS, 1997, p. 527), contudo reprimiu o desejo de picar a mulher. Cabe enfatizar, mais uma vez no texto de Machado, a necessidade de exteriorização dos fenômenos: o autor ilumina o texto bíblico, acrescentando a informação de como o animal se sentia. De fato, quando lemos as Escrituras não nos é revelado o que se passara no coração da serpente ao ver Eva, tal parte fica na escuridão.

Depois de chamar a mulher, a serpente, com a finalidade atrai-la, demostrou que estava comendo do fruto daquela árvore. Impetuosamente, Eva condenou-a: "Desgraçada, é a árvore do Bem e do Mal!” (ASSIS, 1997, p. 527). Ao compararmos este trecho com a Bíblia, notamos que este episódio sucede de modo bem distinto, já que foi o animal que, de maneira astuciosa, primeiro perguntou a Eva: "É assim que Deus disse: Não comereis de toda a árvore do jardim?" (Gn 3, 1). Ela, então, respondeu-lhe, que podia comer de todos os frutos, menos o da árvore da ciência, que estava localizado, no meio do jardim, pois se provasse dele, morreria. Ora, como podemos observar, tanto a Eva do conto quanto a da Bíblia não eram ingênuas, visto que elas se recordavam da ordem de Deus, porém, é claro que a Eva machadiana só conhecia a proibição de Deus, e a personagem bíblica, além disso, sabia qual seria a consequência de seu ato, caso violasse a lei estabelecida.

No texto machadiano, a serpente explicou a mulher, de maneira a convencê-la, que por

https://periodicos.unifap.br/index.php/letras

Macapá, v. 8, n. 3, $2^{\circ}$ sem., 2018 
ter comido o fruto conhecia toda a verdade: "a origem das cousas" e "o enigma da vida” (1997, p. 527). Mas, ela negou a proposta: “Não, pérfida!” (ASSIS, 1997, p. 527). Contudo, o animal insistiu, novamente, através de um discurso muito sedutor:

Néscia! Para que recusas o resplendor dos tempos? Escuta-me, faze o que te digo, e serás legião, fundarás cidades, e chamar-te-ás Cleópatra, Dido, Semíramis; darás heróis do teu ventre, e serás Cornélia; ouvirás a voz do céu, e serás Débora; cantarás e serás Safo. E um dia, se Deus quiser descer à terra, escolherás as tuas entranhas, e chamar-te-ás Maria de Nazaré. Que mais queres tu? Realeza, poesia, divindade, tudo trocas por uma estulta obediência. Nem será só isso toda a natureza te fará bela e mais bela (ASSIS, 1997, p. 527).

Sublinhamos que partir da fala da serpente, Machado de Assis evidência algumas mulheres que foram importantes para a história da humanidade. Dessa maneira, temos o resgate da figura feminina, que sempre foi marginalizada tanto pela igreja cristã quanto pela sociedade patriarcal. Neste sentido, o escritor quer salientar que foi por causa da desobediência da primeira mulher, é que nossa história se constituiu tal qual a conhecemos. E também enfatizar que é por causa dessa desobediência que o mundo veio a ter todos esses feitos.

Cabe comentar que a estudiosa Andreia Amaral assinalou que, neste episódio, o discurso da serpente do conto é muito mais convincente do que o da serpente bíblica, além de ser dito em um tom profético, pois a serpente machadiana prenunciou os acontecimentos, que ocorreriam futuramente a Eva. Desse modo, Amaral afirmou sobre os dizeres da serpente:

A sua capacidade de persuasão é ainda maior do que a que é sugerida no Gênesis, dado que o seu discurso é procedido pelo ato de comer o fruto "da árvore do bem e do mal" (p. 278). Por outro lado, a serpente, em discurso profético [...] vai enumerar uma série de exempla com o propósito de mostrar a Eva o que o fruto lhe reserva (AMARAL, 2004, p. 344).

Concordamos com essa afirmação, uma vez que a serpente machadiana possui uma fala muito rica, dotada de uma série de argumentos atraentes, que poderiam levar ao convencimento: primeiramente de Eva e depois de Adão.

No entanto, a mulher juntamente com Adão reafirmou a resposta de sua recusa. Desse modo, nem a malícia e a sedução da serpente foram suficientes para que o casal desobedecesse à lei de Deus. Segundo o narrador: "Eva escutava impassível; Adão chegou, ouviu-os e confirmou a resposta de Eva; nada valia a perda do paraíso, nem a ciência, nem o poder, nenhuma outra ilusão da terra" (ASSIS, 1997, p. 528). Neste contexto, podemos inferir que o paraíso criado, no conto, era bem atrativo, já que o casal, mesmo ao ser seduzido para obter o conhecimento, negou a proposta e preferiu manter a postura de obediência.

Com efeito em Gênesis, a serpente revelou à mulher que se ela comesse do fruto não morreria, mas seria como Deus, conhecedor do bem e do mal. Eva, então, provou o fruto, e ofereceu a Adão que também o provou. Entretanto, no conto, vimos que o Diabo não conseguiu resgatar sua obra. E Deus, que havia escutado toda a conversa da serpente, ordenou, que um de seus anjos buscasse Adão e Eva para trazê-los a "eterna bem-aventurança" (ASSIS, 1997, p. 528), como forma de recompensa. Assim, o casal foi recebido pelos anjos "ao som de todas as cítaras" (ASSIS, 1997, p. 528), e a terra foi deixada para o Diabo e para a serpente.

Realmente, este final da história da criação machadiana é muito desesperançoso, tal 
como sublinhado pelo pesquisador Fernando Machado Brum. Segundo ele, "as coisas boas que Deus criou não ficaram para nós: não temos acesso ao jardim; não somos filhos daquele Adão e daquela Eva, pois eles subiram aos céus antes de qualquer descendência” (BRUM, 2009, p.139). Delineamos que, em Machado, a história desenvolve-se linearmente e com pouca tensão, ao contrário, da história bíblica, repleta de segundos planos e tensões. Ainda conforme explicitou Brum: "no mundo criado pelo diabo e corrigido por Deus, Adão e Eva não pecaram, foram elevados aos céus e não são os nossos pais (...) e no mundo criado por Deus, o diabo e a serpente conseguem fazer a mulher cair em tentação" (BRUM, 2009, p. 140).

Este questionamento mostra-se bastante pertinente, visto que, no conto, não existe a realidade do pecado. Lá o casal não infringe a lei de Deus. Talvez esta fosse uma estratégia de Machado para nos fazer refletir acerca do texto bíblico, seus personagens, e as grandes temáticas que os envolve, como: a da tentação, da noção do erro e do pecado. Como sabemos, as Escrituras nos narram, que depois do casal provar do fruto, Deus os chamou, mas eles se esconderam, porque descobriram que estavam nus. Dessa forma, o Senhor soube que Adão e Eva haviam desobedecido à sua ordem (Gn 3, 10-11). Se formos analisar, a atitude de Deus, veremos que é contraditória, visto que se Deus é Onisciente, ele já não sabia do que tinha ocorrido? Então, a fim de punir os transgressores ele decretou:

Porquanto fizeste isso, malditas serás mais que toda besta e mais que todos os animais do campo; sobre o teu ventre andarás e pó comerás todos os dias da tua vida. E porei inimizade entre ti e a mulher e entre a tua semente e a semente dela, esta te ferirá a cabeça, e tu lhe ferirás o calcanhar. E a mulher disse: Multiplicarei grandemente a tua dor (...) com dor terás filho (...) E a Adão disse: (...) maldita é a terra por causa de ti; com dor comerás delas todos os dias de tua vida $(G n 3,14-17)$.

Notamos que Deus cruelmente amaldiçoou a serpente, castigou a mulher, multiplicando as dores do parto, e condenou Adão a trabalhar com o suor do próprio rosto. $\mathrm{O}$ crítico Jack Miles em Deus - uma biografia complementou que o Senhor agiu tomado pela fúria, e delineou a qualidade literária deste trecho: "Sua condenação à serpente, à mulher e ao homem, nessa ordem é uma explosão de fúria, e pode-se dizer que se constitui também o grande poema da Bíblia” (MILES, 2009, p. 47).

Convém destacar que Miles também questionou, em seu livro, a respeito da inexplicável atitude de Deus para com os homens: "Por que o Senhor Deus, que pacientemente organizou para o homem um cortejo de todos os animais numa tentativa de achar uma companheira para ele, tem de reagir com uma impaciência tão brutal diante da desobediência da mulher e do erro aparentemente inocente do homem?” (MILES, 2009, p. 49).

$\mathrm{Na}$ história bíblica, a serpente não mentiu, quando disse que os olhos dos homens se abririam, conhecendo o bem e o mal. Diante disso, não sabemos por que motivo não quis Deus, que os homens participassem da consciência divina. Como vimos, no conto, Deus exaltou o obediente casal. Todavia, no relato bíblico, Adão e Eva sofreram a mais profunda humilhação e ainda foram expulsos do paraíso.

Ora, se Deus é bom, por que não perdoou o casal? Assim, observamos que o Senhor se mostrou vingativo e punitivo. Neste contexto, o estudioso Miles pontuou a respeito desta inexplicável ambiguidade, vista no caráter de Deus, depois que os homens o desobedeceram: "Menos de duas páginas depois, o Senhor Deus parece (...) também muito mais vingativo. Pior sua ira é tão gratuita quanto sua generosidade” (MILES, 2009, p. 50). O crítico Eric Auerbach discorreu que até mesmo os personagens bíblicos, portadores da graça 
divina, não estão livres de serem humilhados por Deus. Ele ainda ressaltou que os sentimentos de exaltação e humilhação aparecem sempre interligados na narrativa bíblica:

Pois eles são os portadores da vontade divina, e mesmo assim, são falíveis, sujeitos a desgraça e humilhação - e em meio à desgraça e à humilhação manifesta-se, através das suas ações e palavras, a sublimidade de Deus. Dificilmente um deles não sofre, como Adão, a mais profunda humilhação - e dificilmente um deles não é agraciado pela intervenção e inspiração pessoais de Deus. Humilhação e exaltação são muito mais profundas ou elevadas (...) e, fundamentalmente, andam sempre juntas (AUERBACH, 2007, p. 15).

O desfecho do conto acontece com a constatação do Sr. Veloso de que se a história narrada fosse verdadeira, ele e aquelas pessoas reunidas, não estariam ali provando uma sobremesa. Assim, o conto termina tal como começa, tendo o doce como destaque. De fato, se formos analisar, ele simboliza a tentação, o pecado e o prazer. Na verdade, o autor, através de seu personagem, chega a uma conclusão: só foi por causa da tentação da serpente e do pecado da mulher, é que aquelas pessoas estavam desfrutando do prazer de saborear o doce.

É válido apontar que a pesquisadora Andreia Amaral faz o seguinte comentário, acerca da curiosa metáfora do doce produzida por Machado, de acordo com ela: "A atmosfera da primeira história é também enigmática na medida em que o enigma das origens do homem encontra paralelo metafórico no do doce" (AMARAL, 2004, p. 345).

Neste sentido, Machado de Assis desconstrói o texto bíblico, primeiramente, por fazer com que o Diabo participasse ativamente do processo da criação, e depois ao narrar que o casal, não cedeu à tentação e foi elevado ao céu, sem deixar descendente na terra. Amaral asseverou que Machado: "parodia o discurso genesíaco e depois reconverte esta contranarrativa em hipótese quase improvável, deixando em aberto a questão das origens do mundo e do homem" (AMARAL, 2004, p.346). Dessa maneira, observemos que o escritor resgata a figura do Diabo, criticando a interpretação cristã, além de sublinhar que foi por causa do maligno, que iniciou-se a vida na Terra com todos os seus prazeres.

\subsection{Personagens planos e esféricos}

E então, repentinamente, esse mergulho num dia inteiro de descanso. Deus já é, nesse primeiro momento de sua história, uma mistura de força e fraqueza, de determinação e arrependimento (MILES, 2009, p. 42).

Ao comparamos os personagens do conto com os da Bíblia, observamos uma nítida diferença: os primeiros podem ser descritos como planos, e os outros como esféricos. De acordo com a definição do crítico Antonio Candido, em A personagem de fiç̧ão, as personagens planas: "são construídas em torno de uma única ideia ou qualidade" (CANDIDO, 1987, p. 62) e com a mudança de circunstância, "permanecem inalteradas no espírito" (CANDIDO, 1987, p. 63), já as esféricas estão "organizadas com maior complexidade e, em consequência, capazes de nos surpreender” (CANDIDO, 1987, p. 63). Assim, buscaremos contrastar esses personagens, que aparecem, em ambos os textos, a fim de melhor caracterizá-los.

Comecemos, então, pelo personagem Deus. Em "Adão e Eva", ele realizou alguns feitos, quando o mundo foi criado: corrigiu a obra do Diabo, através do bem, infundiu alma 
e bons pensamentos aos seres humanos e ainda criou um esplêndido jardim para onde os levou. Neste sentido, esse personagem se constitui como um ente delimitado, apresentando um contorno bem definido e construído em torno de uma única ideia: a ele só cabe à qualidade de ser bom e fazer o bem. Também se pode notar que no momento de maior tensão, na ocasião em que a serpente tentou o casal, o Senhor não se manifestou, seu espírito permaneceu inalterado, apenas observou passivamente, pois "ouvira tudo" (ASSIS, 1997, p. 528) o que acontecera. Notemos que no final do conto, a característica bondosa de Deus é reafirmada, a partir do momento, que ele concedeu aos homens uma recompensa por resistirem à tentação do Diabo. Dessa forma, ele conserva, do começo ao fim da narrativa, uma mesma característica, sem oscilar. Já na Bíblia, Deus é um personagem bastante complexo. Assim, no início da criação, O Senhor se demonstrou poderoso e grandioso, ao criar o mundo e suas obras: deu aos homens o benefício de exercerem o domínio sobre todas as coisas da Terra $(G n 1,28)$ e a possibilidade de desfrutarem de um paraíso $(G n 2,15)$, revelando tamanha bondade e generosidade. Todavia, depois que o casal desobedeceu à sua ordem, ele se mostrou outro: vingativo e punitivo, atitude que nos surpreende. De fato, vemos que o caráter do Senhor se modificou, através da mudança de experiência, estabelecida na sua relação com os outros personagens. Mas ao mesmo tempo, que ele castigou os seres humanos, concedeu-lhes também vestimentas $(G n 3,21)$. Assim, Deus se apresenta como um ser incompreensível e em conflito, oscilando seu caráter entre o bem e o mal, manifestando-se como um ser imprevisível, ao contrário do personagem do conto.

Ora, como podemos ver, o caráter de Deus é marcado por ambiguidades, sendo apresentado para os leitores aos fragmentos, demonstrando-se, dependendo da ocasião, ora bom, mal ou arrependido. Auerbach, em Mimeses, sublinhou a respeito da complexidade psicológica vista no Senhor, diante do relato bíblico: "Evidencia-se que até a personagem individual pode ser apresentada como carregada de segundos planos: Deus sempre o é na Bíblia (...) só "algo" dele aparece em cada caso, ele sempre se estende para as profundidades" (AUERBACH, 2007, p. 9).

Ao analisarmos a Eva machadiana, logo percebemos que ela é uma personagem simples e sem profundidade. Relembremos que, no decorrer da narrativa, Eva mostra-se submissa e obediente a um Deus, que lhe estabelece ordens sem nenhum esclarecimento. Mesmo quando a serpente oferece-lhe inúmeros motivos para provar do fruto proibido, Eva não aceita a proposta e responde de imediato, sem fazer nenhuma reflexão, permanecendo-se sempre fiel a Deus. Já a Eva bíblica, é uma personagem complexa. Recordemos que, no episódio da tentação, a mulher ao ver que o fruto da árvore da ciência era apetitoso e desejável, comeu do fruto, e também deu para $\operatorname{Adão}(G n 3,6)$. Logo, ela tem plena consciência do que Deus lhe ordenara, analisando e ponderando os argumentos da serpente. Neste momento, o seu interior encontra-se extremamente excitado entre a obediência e a desobediência a Deus.

Ao observarmos Adão, personagem do conto, vemos claramente que ele possui um contorno bem delineado: é obediente, haja vista que ele não traiu a ordem de Deus, negando a proposta da serpente: "Adão chegou, ouviu-os e confirmou a resposta de Eva" (ASSIS, 1997, p. 529). Entretanto, o personagem bíblico, Adão, é mais complexo, provocando surpresa, ao aceitar provar o fruto, oferecido pela sua mulher, desobedecendo ao Senhor, e ainda percebemos que ele é um personagem em conflito, pois, de acordo com a situação, seu caráter oscila, então Deus o perguntou, porque comeu o fruto, e ele tentou se livrar da culpa, acusando Eva e indiretamente Deus: “(...) A mulher que tu me deste por 
companheira, ela me deu da árvore, e comi” $(G n 3,12)$.

Delineemos que os pensamentos dos personagens bíblicos são mais intricados e possuem mais camadas. Desse modo, esses não são claramente definidos em sua totalidade, tendo o seu caráter revelado aos fragmentos. Nesta perspectiva, Auerbach discorreu:

Mas os próprios seres humanos dos relatos bíblicos são mais ricos em segundos planos (...) eles têm mais profundidade quanto ao tempo, ao destino e à consciência. Ainda que estejam quase sempre envolvidos num acontecimento que os ocupa por completo, não se entregam a tal acontecimento a ponto de perderem a permanente consciência do que lhes acontecera em outro tempo e em outro lugar; seus pensamentos e sentimentos têm mais camadas e são mais intricados (AUERBACH, 2007, p. 9).

Notemos que a serpente do conto se configura como uma personagem plana, na medida em que do começo ao fim da narração, ela permaneceu obediente ao Diabo, cumprindo a função estabelecida pelo seu Senhor: tentar o casal. De fato, essa personagem é bem simples, posto que não detém a capacidade de análise, e então se submete a tudo aquilo que o maligno lhe determina, uma vez que "iria onde ele a mandasse" (ASSIS, 1997, p. 526). Contudo, a serpente bíblica é muito rica em segundos planos, ela não é um ente facilmente delimitável, dado que não conhecemos a sua origem, e quando provocou Eva não sabemos se ela mentia ou dizia a verdade, só depois de concluída a ação de tentar a mulher.

Já o Diabo machadiano é um personagem plano, tendo o seu papel fixado e delimitado: criar o mundo e tentar o casal, através do auxílio da serpente. Percebemos que sua figura não está organizada em torno de uma maior complexidade, e não vemos nenhuma atitude capaz de nos surpreender, visto que quando esse personagem fica sabendo do que Deus fizera com o casal, ele não vai diretamente ao paraíso, mas manda uma representante. Em suma, como constatamos o Deus bíblico é um ser complexo. Ora, se ele criou os seres humanos a sua imagem, logo esses foram originados, a partir da complexidade de seu criador. Em Machado, tal concepção é semelhante, pois o Diabo, criador de todas as coisas da terra, é descrito como um ser simples, e assim se os homens do conto foram criados, por meio da imagem do Diabo, e complementados por um Deus também simples, eles derivam da simplicidade destes.

\section{Referências}

AMARAL, Andreia. Travessias nos jardins das delícias: Machado e Eça; Revista da Faculdade de Letras_Linguas e Literaturas, II série, vol. XXI, Porto, 2004, p.337-349. Disponível em: $<$ http://ler.letras.up.pt...>. Acesso em: 18 março 2013

ASSIS, Machado de. Obra Completa. Vol. I. Rio de Janeiro: Editora Nova Aguilar S.A, 1997.

. Obra Completa. Vol. II. Rio de Janeiro: Editora Nova Aguilar S.A, 1997.

. Obra completa. São Paulo: Editora Brasileira LTDA, 1962.

. Obra completa. Rio de Janeiro, Porto Alegre, São Paulo: W. M. Jackson Inc,

Editores, 1962. (31v.)

AUERBACH, Erich. Mimesis. São Paulo: Editora Perspectiva, 2007.

BÍBLIA SAGRADA. Trad. João Ferreira de Almeida. Edição revista e corrigida. São Paulo: Sociedade Bíblica do Brasil, [s.d]. 
BRUM, Fernando Machado. Literatura e Religião: Estudos das referências religiosas na obra de Machado de Assis. (Mestrado em Literatura Brasileira). Universidade Federal do Rio Grande do Sul, Porto Alegre, RS, 2009. Disponível em: <http://www.lume.ufrgs.br... >. Acesso em: 28 novembro 2012

CANDIDO, Antonio. A personagem da ficção. São Paulo: Editora Perspectiva, 1987.

CARVALHO, Maria Teresa. Literatura e Religião. São Paulo: Terceira Margem, 2004. FLUSSER, Vilém de. A história do Diabo. São Paulo: Editora Annablume, 2006.

MILES, Jack. Deus - Uma biografia. Trad. José Rubens Siqueira. São Paulo: Companhia das Letras, 2009. 